Review Article

\title{
Molecular and Biological Basis of Lung Cancer-Part I
}

\section{Nikolaos Andreas Chrysanthakopoulos*}

*Corresponding author: Nikolaos Andreas Chrysanthakopoulos

Address: DDSc, Oncologist (MSc Oncol), Implant Surgeon (Cert. Att), RN, 35, Zaimi Street, PC 26 223, Patra, Greece

e-mail $₫$ nikolaos_c@hotmail.com,nchrysant@med.uoa.gr

Received: 13 March 2020; Accepted: 30 March 2020

\begin{abstract}
Lung cancer (LC) consists the 5th leading cause of death worldwide, and an important cause of morbidity and mortality, nowadays, as the 5-year survival is extremely poor. LC molecular biology may lead to customized treatment based on targeting specific genes and signaling path-ways. The main signaling pathways in LC development concern growth promoting pathways such as EGFR/Ras/PI3K, growth inhibitory pathways such as p53/Rb/P14ARF, STK11, apoptotic pathways such as Bcl-2/Bax/Fas/FasL, and DNA repair and immortalization genes. Epigenetic alterations in LC are also responsible for cell transformation by modifying chromatin structures and the specific expression of genes and are involved in tumor suppressor genes silencing whereas enhancing oncogenes expression. In the present review, is presented the current state of knowledge regarding the cascade of events that are associated with LC development giving emphasis to oncogenes, tumor suppressor-genes and signaling pathways that are implicated in LC development. Those aberrations and abnormalities allow cells to escape the normal regulation of cell division, apoptosis and invasion. A better understanding of the molecular basis of LC and especially the identification of biologically significant genetic alterations in LC that lead to activation of oncogenes and inactivation of tumor suppressor genes could provide hypotheses for molecular early detection and targeted therapeutic strategies.
\end{abstract}

Keywords: Cancer, Molecular biology, Lung cancer

\section{Introduction}

In 2012 according to WHO report 1.8 million people were suffered from LC, whereas 1.6 million deaths were recorded worldwide (WHO, 2014a). Those observations lead to the conclusion that LC is the most common cause of cancer-related death in males and the second most common in females after breast cancer (WHO, 2014b). LC was the leading cause of cancer-related death in males and females in the United States, and was estimated $28 \%$ of total cancer deaths in 2010 (Jemal et al., 2010). 
Cancer development is characterized by genetic alterations in DNA sequence and epigenetic ones that contribute to cancer initiation, promotion and progression as regulate gene expression and cellular signaling pathways in the normal cells. Those alterations usually occur early in malignant transformation (Geutjes et al., 2012). LC pathogenesis has not been fully elucidated, whereas LC molecular basis is complicated and heterogeneous. Previous investigations have shown that LC consists a multistage process in which genetic and epigenetic alterations are implicated, particularly activation of growth promoting pathways and inhibition of tumor suppressor pathways, that can lead to cause DNA damage, a procedure responsible for the transformation of lung epithelial cells into malignant (Sekido et al., 1998). The susceptibility to that malignant transformation concerns possibly all lung cells, epithelial, or stem cells, whereas the tumor-initiating cell show specific mutations and acquire additional during the tumor development (Nowell, 1976).

According to histological features, clinical, and neuroendocrine characteristics, LC includes two main types, non-small cell LC (NSCLC) and small cell LC (SCLC), whereas their prevalence is 80\%-85\% and $15 \%-20 \%$, respectively. Those types have also differences in molecular basis. NSCLC is divided into the following histological subtypes, adenocarcinoma (ADC), squamous carcinoma (SQC), large-cell carcinoma (including 1 arge-cell neuroendocrine LC), bronchoalveolar LC, and mixed histologic types (e.g, adenosquamous carcinoma) (Gazdar, 2010).

Common molecular differences among NSCLC subtypes and between NSCLC and SCLC are associated with oncogenic mutations, gene amplification, increased protein expression, tumor suppressing alterations which include mutations, deletion and loss of heterozygocity ( $\mathrm{LOH}$ ), loss of protein expression, tumor-acquired DNA methylation, chromosomal aberrations, and presence of telomerase activity. Those genetic alterations implicate various cellular signaling pathways that are involved in cell functions such as cell growth, differentiation, proliferation, survival, programmed cell death, invasion, metastasis, etc., and include several oncogenes (ONCG) and tumor suppressor genes (TSG), such as BRAF, KRAS, MET, PIK3CA, EGFR, ErbB2/HER2-neu, MDM2, MYC, NKX2-1, PDGFRA, c-KIT, CD44, Bcl-2, CCND1, CRK, p53, PTEN, Rb, LKB1, CDKN2A (p16/p14ARF), FHIT, CAV1, APC, TUSC2 (FUS1), CDH 1, CDH 13, DAPK1, GSTP1, MGMT, RAR $\beta$, RASSF1A, SEMA3B, TIMP3, EML4-ALK fusion, etc. (Larsen and Minna, 2011) .

Other mechanisms that are implicated in LC development are epigenetic ones. Epigenetics is the alteration in gene expression without changing the nucleotide sequence. Activation and inactivation of cancer-associated genes which promote or prevent their development can occur by epigenetic mechanisms which concern gene regulation and conclude DNA methylation, histone deacetylation, chromatin remodeling, small non-coding RNA expression and gene imprinting. In recent years, epigenetic mechanisms have been investigated in a number of tumor types and epigenetic biomarkers have been identified and are suitable for cancer detection, diagnosis, follow-up of treatment and screening high-risk populations. Epigenetic abnormalities consist targets for cancer therapy as regulators that are able to inhibit 
histone deacetylases and demethylate DNA, can lead to the reactivation of silenced genes (Banerjee and Verma, 2009).

\section{Genomic Instability, Oncogenes and Tumor-Suppressor Genes}

One of the main hallmarks of cancer is genomic instability that is obvious in LC (Sekido et al., 1998), whereas the identification of gene amplification and deletions in cancer genome has led to the discovery of many ONCGs and TSGs (Larsen and Minna, 2011; Cooper et al., 2013).

TSGs consist critical negative regulators of normal cell growth and the loss of a TSG function is responsible for cancer pathogenesis. According to Knudson's two hit hypothesis, carcinogenesis is associated with both gene alleles inactivation. Abnormalities such as mutation, epigenetic silencing or other aberrations lead to the inactivation of the gene in one allele, and the second one is often inactivated through loss of heterozygosity ( $\mathrm{LOH}$ ) in which is lost a chromosome region by genetic aberrations such as deletion, non-reciprocal translocation or mitotic recombination (Knudson, 1993a). A crucial step in lung tumorigenesis is the loss of TSGs function, and is usually caused by inactivation of both alleles. In that process $\mathrm{LOH}$ inactivates one allele through chromosomal translocation or deletion, and other aberrations such as point mutation, epigenetic, or transcriptional silencing inactivate the second allele (Knudson, 1989; Breuer et al., 2005).

Commonly inactivated TSGs in LC concern TP53, RB1, STK11), CDKN2A, FHIT, RASSF1A and PTEN and the chromosomal locations with allelic loss in LC concern mainly TP53 (17p13), RB (13q12), CDKN2A (9p21), and PTEN genes (10q22) (Ding et al., 2008; Larsen and Minna, 2011). Moreover, activation of ONCGs such as MYC, RAS, EGFR, B-RAF, ErbB2/HER2-neu, MET, NKX2-1, PDGFRA, CD44, BCL-2, PIK3CA, MDM2, c-KIT, SOX2, FGFR2, CRKL, CDK4, EML4-ALK fusion, and CCND1 due to gene amplification, overexpression, point mutation, or DNA rearrangements (Fong et al., 1995a; Sekido et al., 1998; Larsen and Minna, 2011; Cancer Genome Atlas Research Network, 2012 ) can lead to insistent upregulation of mitogenic growth signals that can induce cell growth as the cell depends on that abnormal oncogenic signaling for survival have also involved in LC development.

Genetic aberrations have been linked with LC development such as gain at 1q, 3q, 5p, and 17q, specific allelic loss at 3p, 4q, 5q, 9p, 11p, 17p, and18q (Fong et al., 1994; Fong et al., 1995a; Fong et al., 1995b; Fong et al., 1995c; Sanchez-Cespedes et al., 2001; Sekido et al.1998; Sekido et al., 2003; Weir et al., 2007) (Table 1).

One of the most frequent and early genetic alterations in cancer is LOH or allele loss of one copy of 3p chromosome which has been observed in $78 \%$ of lung preneoplastic lesions and in 96\% of LC cases. On chromosome 3p are located various genes that function as TSGs, such as FHIT (3p14.2), RASSF1A, TUSC2/FUS1, semaphoring family members SEMA3B and SEMA3F (3p21.3), and RARb (3p24) (Fong et al., 1999; Wistuba et al., 2000). RASSF1A, FHIT, TUSC2, and SEMA3B TSGs are able to reduce malignant 
cell growth in case they will be introduced into LC cells (Siprashvili et al., 1997), whereas RASSF1A, FHIT, SEMA3B, and RARb TSGs often show decreased expression in LC cells due to the promoter hypermethylation as an epigenetic mechanism (Ito et al,. 2005; Zochbauer-Muller et al., 2007; Feng et al., 2008).

\section{Epigenetic Mechanisms}

Epigenetics is the study of heritable phenotype changes that do not involve alterations in the DNA sequence. Epigenetic mechanisms are essential for normal development and maintenance of tissue specific gene expression standards in human. Epigenetic processes deregulation can lead to altered gene expression and function and thus in malignant cellular transformation and those alterations consist a hallmark of cancer. Cancer initiation and progression as a genetic disease implicates epigenetic abnormalities and genetic alterations. Recent researches have shown that the association between cancer and epigenetics concerns alterations such as DNA methylation ( $\mathrm{CpG}$ island methylations), histone modifications (methylation, phosphorylation, acetylation, ubiquitylation, and sumoylation), chromatin remodeling, nucleosome positioning and non-coding RNAs, specifically microRNA expression. Epigenetic abnormalities have a reversible nature and a new field of epigenetic treatment is in progress in an effort to discover epigenetic drugs for cancer treatment (Sharma et al., 2010) (Figure 1).

DNA methylation can lead to gene silencing and post-translational modifications of histones, alterations that are implicated in gene expression abnormalities in cancer development and progression. It has been recorded that aberrant hypermethylation in $5^{\prime}-\mathrm{CpG}$ islands in the promoter regions is a mechanism for silencing TSGs or other cancer-associated genes in various cancers (Herman and Baylin, 2003; Cho et al., 2010). The abnormal methylation of normally unmethylated CpG-rich areas of the promoter location can lead to the silencing of mRNA expression, and this epigenetic alteration is considered to be a significant mechanism for inactivation of those TSGs in LC development (Sulewska et al., 2007). The loss of TSGs function can prevent inhibition of cancer cells growth, and can lead to malignant transcription and translation during DNA replication. Genes, such as the RASSF1A, cyclin-dependent kinase inhibitor (p16), and MGMT DNA repair gene, are methylated in LC (Kurakawa et al., 2001; Gao et al., 2012). In LC has been found abnormal promoter methylation in genes such as the TSGs DAPK and RASSF1A. DAPK gene is located on chromosome 9q34.1 and encodes a pro-apoptotic protein which implicated in the apoptosis initiated by IFN- $\gamma$, Fas and TRAIL. Aggressiveness of malignancies have been associated with the methylation of the DAPK gene promoter location and the DAPK expression loss. The expression was partially restored after treatment with 5'-aza-2'-deo-xycitidine, which consists a demethylation agent, indicating a role for methylation in down regulation of DAPK (Tang et al., 2000). 


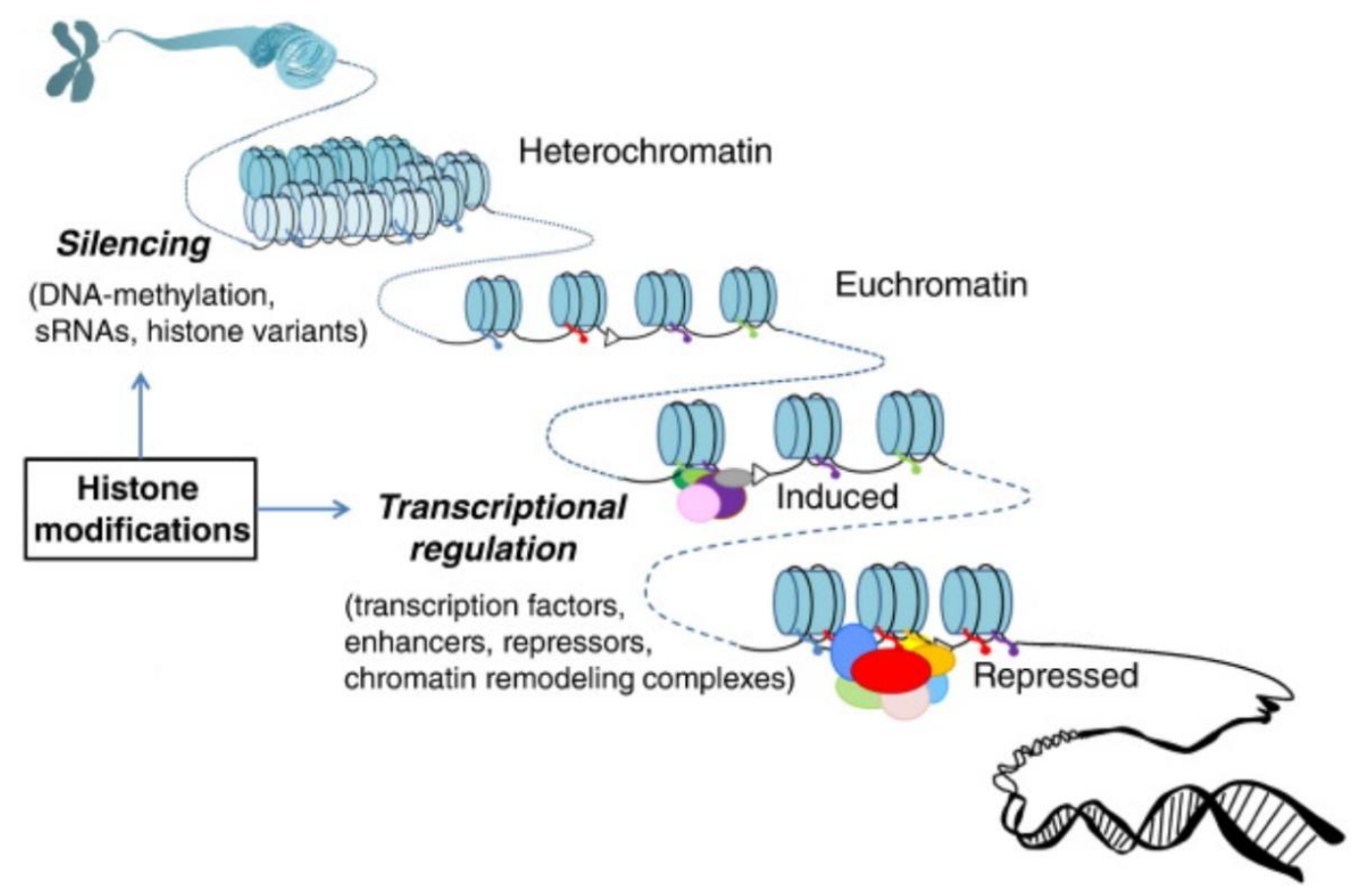

Figure 1. Epigenetic alterations

\section{Oncogenes and LC}

KRAS belongs to the proto-oncogenes RAS family which contains KRAS, NRAS and HRAS genes, and is implicated in RAS-RAF-MEK-MAPK/ERK transduction pathway which regulates cell survival, cell cycle progression, differentiation and cell motility (Downward, 2003). The RAS/RAF/MEK/MAPK pathway plays a critical role in many LC development with at least one mutation in the pathway (Ding et al., 2008), however, the most common are mutations in KRAS. KRAS activating mutations are the commonest in LADC cases and have been observed in 25-40\% of those cases (Ding et al., 2008; Riely et al., 2008; Schmid et al., 2009), are very rare or absent in SQCLC and SCLC cases (Rekhtman et al., 2012), whereas NRAS and HRAS activating mutations are rare in LADC cases (Cooper et al., 2013). KRAS mutations concern $\mathrm{G}$ to $\mathrm{T}$ transversions in smokers, whereas never smokers are more likely to have $\mathrm{G}$ to $\mathrm{A}$ transitions (Riely et al., 2008). In SCLC was identified only one KRAS mutation in codon 61 (Cancer Genome Atlas Research Network, 2012) and in LADC was found a single amino acid substitution in hotspots located mostly in codon12 but also more rarely in codons 13 and 61 (Downward, 2003).

The MYC proto-oncogene consists one of the main downstream effectors of the RAS/RAF/MEK/MAPK signaling pathway. Under normal conditions this transcription factor is responsible for keeping tight control of cellular proliferation, however, its amplification or overexpression leads to aberrant expression and has been observed in LC cases (Richardson and Johnson, 1993). Gene amplification is the main mechanism for the MYC members activation and is observed frequently in NSCLC cases (Nau et al.1986), whereas MYCL and -N along with MYC, are usually activated in SCLC cases (Broers 
et al.1993; Fong et al., 1999). Increased C-MYC expression has been shown to induce mitosis or apoptosis, depending on the availability of other critical growth stimuli. In the presence of such stimuli, C-MYC acts as a classic proto-oncogene stimulating mitosis, whereas in the absence of such stimuli, it initiates apoptosis (Kerr et al., 1994).

$\mathrm{BRAF}$ is a gene that encodes a serine/threonine protein kinase, called B-RAF. The gene is also referred to as a proto-oncogene B-RAF and V-RAF murine sarcoma viral oncogene homolog $\mathrm{B}$, while the protein is more formally known as serine/threonine-protein kinase B-RAF, that is the downstream KRAS effector protein and activates the MAPK pathway which is implicated in the regulation of cell survival and proliferation (Davies et al., 2002). Following activation, B-RAF phosphorylates downstream mediators MEK1 and -2 which, in turn, activate ERK1 and ERK2, that is implicated in regulation of growth regulating factors, c-JUN and ELK1(Downward, 2003). B-RAF activating mutations increase kinase activity that display transforming activity in vitro (Davies et al., 2002). Those mutations are rare in NSCLC cases (Brose et al., 2002; Schmid et al., 2009; Davies et al., 2002; Paik et al., 2011), however activating mutations in NSCLC cases are not the same with those in colorectal cancer and melanoma, showing a lower rate of V6ooE mutations that influence the protein kinase domain. In LADC cases, V60oE mutations in exon 15 have been estimated to be $50 \%$ of B-RAF mutations followed by G469A in exon 11 and D594G in exon 15 (Marcheti et al., 2011). In NSCLC cases some of the B-RAF mutations have been observed in the kinase domain, such as V60oE, D594G and L596R, whereas others have been found in the activation domain G-loop of the B-RAF gene, such as G465V and G468 A (Davies et al., 2002). B-RAF mutations have been observed mainly in LADC cases as already mentioned, whereas non-V6ooE B-RAF mutations have been 1 inked to current /former smokers and V60oE mutations are more frequent in females never smokers (Marcheti et al., 2011; Paik et al., 2011).

MEK1 or MAPK1 is a serine-threonine kinase, functions as a downstream target of RAS activation, as activates MAPK2 and MAPK3 downstream of B-RAF (Downward, 2003). Few cases of somatic mutations of MEK1 have been identified in LADC cases and carried an activating mutation in exon 2 that did not implicate the kinase domain (Marks et al., 2008).

MET consists a proto-oncogene which is located on chromosome 7q21-q31 and encodes a membrane receptor tyrosine kinase (RTK), HGFR (hepatocyte growth factor receptor). Following binding of its ligand HGF, interactions have been observed in which are involved the RAS/RAF/MEK/MAPK, PI3K/AKT and c-SRC kinase downstream pathways (Sadiq and Salgia, 2013). In NSCLC cases, MET is changed by gene amplification (Cappuzzo et al., 2009; Onozato et al., 2009; Beau-Faller et al., 2008), whereas increased MET copy number is mutually exclusive with KRAS mutations (Beau-Faller et al., 2008; Onozato et al., 2009) and are more common in SQCLC than in LADC cases. MET mutations have been found in 3-5\% of LADC cases (Ding et al., 2008; Onozato et al., 2009). 
ROS1 is a proto-oncogene, encodes a transmembrane RTK that has high homology with ALK in its protein kinase domain and is located on chromosome 6q22. Its activation implicates the RAS/MAPK/ERK, $\mathrm{PI} 3 \mathrm{~K} / \mathrm{AKT} / \mathrm{m}$ TOR, and STAT3 pathways (Chin et al., 2012). ROS1 fusion was identified in a NSCLC cell line SLC 34A2-ROS1 and a patient sample CD 74-ROS1 (Rikova et al., 2007). Another inframe fusion KDELR2-ROS1 was found, in a LADC sample from a non-smoker (Govindan et al., 2012), whereas ROS1 rearrangements were identified in a lower rate in LADC cases (Bergethon et al., 2012; Takeuchi et al., 2012). In addition, ROS1 rearrangements were presented in younger ages, never smokers or in Asian population (Bergethon et al., 2012) similar to ALK rearrangements (Shaw et al., 2009).

Fibroblast growth factor receptor 1 (FGFR1), is a membrane RTK whose ligands are specific members of the fibroblast growth factor family and regulates cell proliferation through activation of the PI3K and MAPK pathways (Tran et al., 2013). In SQCLC cases FGFR1 somatic gene amplifications have been identified (Turner and Grose, 2010), whereas FGFR1 amplifications show in vitro an oncogenic effect on NSCLC cell lines (Dutt et al., 2011). Those abnormalities have not found in LADC cases (Cancer Genome Atlas Research Network, 2012; Dutt et al., 2011). The PIK3CA ONCG is involved in p110 alpha (p110a) protein formation, which is one subunit of the enzyme PI3K. The p110a protein performs the action of $\mathrm{PI}_{3} \mathrm{~K}$. PI3K signaling is important for cell activities, such as cell growth, proliferation, migration, production of new proteins, transport of materials within cells, cell survival, whereas affects cancer and metabolic disorders (Engelman et al., 2006; Yuan and Cantley, 2008; Courtney et al., 2010). PIK3CA gene mutations have been observed in various human cancers and in NSCLC cases, affect the helical binding domain (exon 9, E545K or E542K) or the catalytic subunit (exon 20, H1047R or $-7 \mathrm{~L}$ ) and are considered oncogenic (Samuels and Velculescu, 2004; Huang et al., 2007; Engelman et al., 2008; Ding et al., 2010). PIK3CA mutations in LADC cases have not been described to be mutually exclusive, finding that is not in accordance with classical oncogenic driver mutations like activating EGFR mutations, whereas are associated with EGFR, BRAF, ALK and, mainly, KRAS aberrations, thus it remains unclear if PIK3CA mutation alone is a sufficient event for NSCLC development (Yamamoto et al., 2008; Chaft et al., 2012). Similarly, the role of PIK 3 CA mutations in SQCLC cases is not obvious yet (Dearden et al., 2013), despite the fact that an association between SQCLC and PIK 3 CA mutations in a frequency of $4.2 \%$ was recorded (Yuan and Cantley, 2008).

Platelet-derived growth factor receptors (PDGFRs), with the members PDGFR $\alpha$ and $-\beta$, consist a family of cell surface type III RTK (Shim et al., 2010). Following binding of the ligands, the receptor complex is activated and interacts with several signaling molecules, such as PI3-K, GTP-ase activation protein (RASgap), growth factor binding protein (Grb2), and is implicated in the PI3-K, RASMAPK, and STAT3 pathways (Montmayeur et al., 1997; Cancer Genome Atlas Research Network, 2012; Tian et al., 2014). PDGFR signaling regulates biological functions, such as cellular growth, proliferation, differentiation, migration, invasion, angiogenesis and metastasis (Cooper et al., 2013). 
Deregulated PDGFR signaling has been implicated in the pathogenesis of several diseases and plays a crucial role in the development and progression of human malignancies such as breast, gastric, prostate, lung, colon, and other cancers (Coltrera et al., 1995; Tejada et al., 2006). PDGFRA somatic gene amplifications have also been found (Cancer Genome Atlas Research Network, 2012).

The RTKs of the ErbB family is consists of 4 members, EGFR, ErbB-2(HER2), ErbB-3, and -4, are able to form homodimers and heterodimers and also to bind different ligands which leads to the activation of the receptor (Normanno et al., 2005). EGFR signal transduction activation is associated with RAS/RAF/MAPK/PI3K/AKT/m TOR, and JAK/STAT pathways (Scaglioti et al., 2004; Sordella et al., 2004). EGFR is implicated in the regulation of various oncogenic functions such as survival, cell proliferation, differentiation, invasion, metastasis, and neovascularization (Sordella et al., 2004), whereas aberrations, such as activating mutations, associated with EGFR are implicated in the pathogenesis of several tumors, including NSCLC, as are able to lead to constitutive tyrosine kinase activation (Sordella et al., 2004; Greulich et al., 2005) and oncogenic transformation of lung epithetlial cells in vitro (Greulich et al., 2005). Increased protein expression or increased gene copy number are additional mechanisms of increased EGFR signaling (Okabe et al., 2007; Dahabreh et al., 2010). In 50\% to 90\% of NSCLC cases has been observed EGFR overexpression or abnormal activation. Mutations in EGFRs, caused by exon19 deletion or exon21 L858R mutation, show an increased rate and duration of EGFR activation compared with wild-type receptors and prefer the activation of the $\mathrm{PI}_{3} \mathrm{~K} / \mathrm{AKT}$ and STAT3/-5 pathways rather than the RAS/RAF/MEK/MAPK pathway (Sordella et al., 2004). In NSCLC cases, EGFR mutations have been identified in the first four exons of the intracellular tyrosine kinase domain, mainly in exon 19 in frame deletions, concerns over 20 variants, and the most common is the delE746-A750. Other EGFR mutations are missense, and mainly a single nucleotide point mutation in exon 21 that leads to a single amino acid change from leucine to arginine at codon 858, L858R (Yip et al., 2013). However, less frequent mutations have been identified in exon 20, insertions or frame duplications (Tam et al., 2006; Yamamoto et al., 2006). The majority of EGFR mutations have been observed in LADC cases (Kosaka et al., 2004; Shigematsu et al., 2005) and few in adenosquamous (ADS) carcinomas and very rare in SQCLC cases (Ohtsuka et al., 2007; Rekhtman et al., 2012), however in SQCLC cases copy-number gains, protein overexpression and variant-III mutations which involve the extracellular domain of EGFR are common findings in those cases than in LADC (Heist et al., 2012). EGFR mutations are strongly associated with the LADC histology and never smokers, (Fujino et al., 1996; Franklin et al., 2002; Shigematsu et al., 2005), whereas the observed resistance to tyrosine kinase inhibitor therapy has been associated with KRAS mutation, or MET protooncogene amplification, or EGFR exon-20 insertions or a secondary T790M mutation (Pao et al., 2005a; Pao et al., 2005b; Engelman et al., 2007; Gazdar, 2009) in which MET activates the PI3K pathway through phosphorylation of ERBB3, a process that is not associated with EGFR and ERBB2 (Engelman et al., 2007). In LADC cases, activated mutant EGFR induces high levels of interleukin (IL)-6, and can lead to STAT3 activation (Gao et al., 2007). 
HER 2 activation leads to signaling through a sequence of signal transduction pathways such as PI3K, MAPK and JAK/STAT (Graus-Porta et al., 1997) and its activation has been observed in few cases of LC with overexpression in $20 \%$ of cases, activating mutations in $1.6-4 \%$ and gene amplification in $2 \%$ (Heinmöller et al., 2003) of NSCLC cases.

HER2 activating mutations concern exon 20 in frame insertions of 3 to12 base pairs in length (Shigematsu et al., 2005). HER2 genetic aberrations have been identified mainly in LADC cases (Shigematsu et al., 2005; Tomizawa et al., 2011; Cancer Genome Atlas Research Network, 2012) and mutations in tumors which consist the wild-type for EGFR and KRAS (Shigematsu et al., 2005; Cancer Genome Atlas Research Network, 2012) may be are associated with females and non-smokers (Shigematsu et al., 2005; Tomizawa et al., 2011).

Cyclin D1 (CCND1) is one of the more important human ONCG, involved in the pathogenesis of multiple tumor types. In normal cells, cyclin D1 forms complexes with cyclin-dependent kinases (CDK), activates those and regulates transcription process. Cyclin D1 protein is frequently overexpressed in various cancers, as in a rate $5-20 \%$ of tumors occurs cyclin D1 gene amplification. In NSCLC cases CCND1is amplified and the protein is overexpressed in tumors and preinvasive bronchial lesions. Its deregulation is implicated in bronchial neoplasia and its overexpression is a critical event for malignant transformation in the lung and other tissues (Gautschi et al., 2006). CCND1 overexpression through gene amplification or other gene abnormalities has been identified in about 40\% of NSCLC cases. In NSCLC cases, the pathway is deactivated mainly because of the alterations of CCND1, CDK4 and the cyclin dependent kinase inhibitor p16 (CDKN2A) (Brambilla et al., 1999).

B-cell-lymphoma-2(Bcl-2) is a mitochondrial apoptotic pathway regulator and promotes survival by inhibition of adapters which are necessary for the activation and cleavage of caspases. Bcl-2 protooncogene is encoded by a $230 \mathrm{~kb}$ gene and its major function appears to be to inhibit programmed cell death (apoptosis), to prolong cell survival by arresting cells in the cell cycle Go/G1 phase and is overexpressed in various human tumors including LC (Anagnostou et al., 2010; Lawson et al., 2010).

However, the role of the antiapoptotic protein Bcl-2 in LC remains controversial. In addition, transregulatory mechanisms appear to be responsible for the Bcl-2 protein high levels production that occur in many different solid tumors and LC (Pezzella et al., 1993; Fontanini et al., 1995). Bcl-2 protein is a known inhibitor of the p53-dependent and independent apoptosis pathway, at high levels protects cells apoptosis induced by C-MYC or wild-type p53 (McDonnell et al., 1993; O'Neill et al., 1996). However, the associations of those proteins, the correlation of their expression and the prognosis of LC are still controversial (Pezzella et al., 1993; Gaffney et al., 1994; Anton et al., 1997). The RET proto-oncogene is located on chromosome 10q11.2 and encodes a RTK for members of the glial cell line-derived neurotrophic factor (GDNF) family of extra-cellular signaling molecules (Knowles et al., 2006). RET gene gain of function mutations are associated with the development of various types of human cancer, including medullary thyroid carcinoma, 
multiple endocrine neoplasias (MEN) type $2 \mathrm{~A}$ and $2 \mathrm{~B}$, pheochromocytoma and parathyroid hyperplasia (Wells and Santoro, 2009), whereas the activation of RET through chromosomal rearrangement has been found in a low rate of LC cases (Ju et al., 2012; Kohno et al., 2012; Lipson et al., 2012). The functional RET kinase domain from exons $12-2 \mathrm{O}$ is fused to $\mathrm{KIF}_{5} \mathrm{~B}$ (kinesin family $5^{\mathrm{B}}$ ) and encodes a coiled-coil domain which is involved in organelle trafficking (Ju et al., 2012; Kohno et al., 2012). KIF5B-RET fusions have been found in 1-2\% of LADC cases (Kohno et al., 2012; Lipson et al., 2012) and have also been found to be mutually exclusive of other driver mutations which involve EGFR, KRAS or ALK genes. RET rearrangements were identified in $6.3 \%$ of LADCs cases, in never or light smokers that are known to be wild type for other driver mutations (HER2, ALK, EGFR, KRAS, BRAF and ROS1) (Ju et al., 2012; Kohno et al., 2012; Lipson et al., 2012).

DDR2 (discoidin domain receptor tyrosine kinase 2) is a gene that encodes a RTK known as the discoidin domain-containing receptor 2 protein. Binding of collagen to DDR2 leads to the activation of the downstream SRC and STAT pathways. Similar to integrin receptors, DDR2 may play a role in modulating cellular interactions with the extracellular matrix and is implicated in the regulation of survival and cell proliferation (Ikeda et al., 2002). DDR2 mutations have been found in multiple tumor types, including LC, brain, breast, gynecologic, and prostate cancer (Valiathan et al., 2012), whereas mutations in DDR2 were found in 3.8\% of SQCLC cases (Hammerman et al., 2011). The c-kit proto-oncogene encodes a transmembrane tyrosine kinase growth factor receptor which belongs to the PDGFR family (Yarden et al., 1997). Its ligand SCF (kit-ligand or steel factor) is a hemopoietic growth factor that supports the proliferation of multiple hemopoietic cell lines (Ashman, 1999). Similar studies showed that SCLC cell lines and tumors express the mRNA for the ckit receptor and for SCF, suggesting that these gene products constitute an autocrine loop mediating tumor cell survival and growth. However, most of this knowledge is derived from cell culture experiments or animal models and is based on RNA or DNA analysis only. The clinical impact of ckit protein expression in SCLC patients remains unknown (Hibi et al., 1991; Krystal et al., 1996).

SOX2 is a stem cell transcription factor and plays a critical role in the embryonic development regulation as consists one of the genes (Oct4, $\mathrm{SOX} 2, \mathrm{Nanog}$ ) that are able to reprogram human somatic cells to pluripotent stem cells. Overexpression of SOX2 has been observed in all types of LC tissues.

Amplification of the region 3q, the most common genomic aberration in SCLC, has been found in the evolution of pre-invasive SQCLC and involves SOX2 as a key target of this process. SOX2 is expressed in nearly $20 \%$ of LADC cases and is associated with poor prognosis (Karachaliou et al., 2013).

After analyzing of SCLC cell lines, $\mathrm{H} 446$ and $\mathrm{H} 720$ was found that SOX2 is amplified in approximately $27 \%$ of cancers (Rudin et al., 2012). In addition, it has been observed that SOX2 amplification and consequent SOX2 protein overexpression represent important mechanisms of tumor initiation and progression in a considerable subset of SQCLC cases (Maier et al., 2011). Immunohistochemical analysis of SOX2 expression in various types of LC revealed that SCLC tissues 
showed a higher SOX2 expression level than in NSCLC tissues, whereas SOX2 was found to cooperate with crucial ONCGs like Wnt1, Wnt2, C-Myc and Notch to promote lung tumor occurrence, whereas downregulation of SOX2 inhibited proliferation and induced apoptosis in tumor cells (Chen et al., 2012). SOX2 was found to be strongly and diffusely expressed in approximately $90 \%$ of SCLC and 20\% of LADC cases (Sholl et al., 2010a). As previously described, SOX2 gene amplification is more common in the SCLCs of smokers while the incidence of SOX2 amplification is in the early stage of tumorigenesis in NSCLC. However, SOX2 is also activated in more advanced SQCL tumors (Sholl et al., 2010b; Hussenet et al., 2010). Therefore, the SOX2 gene is not only activated by amplification but is also affected by other regulators that promote its transcription, affecting its downstream genes. Somatic gene amplifications have been found in SCLC cases in a number of genes including SOX (Cancer Genome Atlas Research Network, 2012).

NKX2-1, also known as TTF-1 (thyroid transcription factor-1), is a tissue-specific transcription factor of the thyroid, lung, and ventral forebrain. It has been shown to play a critical role in lung development, LC differentiation and morphogenesis (Li et al., 2012), as encodes a lineage-specific transcription factor which is crucial for branching morphogenesis in lung development, as mentioned and the type II pneumocytes formation, the cells which cover the internal surface of lung alveoli (Ikeda et al., 1995; Bingle, 1997). The oncogenic role of NKX2-1 in LADC cases has been extensively investigated (Tanaka et al., 2007; Weir et al., 2007; Kwei et al., 2008) however, it was found the suppressive role of LADC progression by NKX2-1(Winslow et al., 2011).

Mouse double minute2 homolog (MDM2) is an oncoprotein that is encoded by the MDM2 gene, consists an important negative regulator of the p53. MDM2 ligates the p53 protein via its E3 ubiquitin ligase, and the ubiquitinated p53 can be transferred to the cytoplasm and degraded by proteasomes. Therefore, MDM2 can maintain the stability of p53 pathway. MDM2 gene amplification and overexpression of its protein have been found in some malignancies, and can lead to tumorigenesis through inactivation of the p53 function, as shows a large effect on the antitumorigenic activity of the p53. Its amplification has been detected in LC, colon cancer and other malignancies (Higashiyama et al., 1997).

CRK is an adapter molecule, also known as proto-oncogene c-Crk. CRK family of adaptor proteins are cellular homologues of v-Crk (Mayer et al., 1998). Those adaptor proteins are widely expressed and are implicated in signal transduction from various receptors, signaling scaffold proteins, and oncoproteins and affect cellular proliferation, differentiation, and migration. Its role as mediated signal transduction protein contains ONCGs such as EGFR, Met, PDGF, BCR-ABL, Tel-Abl, VEGFR, erythropoietin receptor, and insulin receptor substrate (Feller, 2001; Birge et al., 2009). CRK overexpression has been identified in NSCL, colon and brain cancers (Miller et al., 2003; Takino et al., 2003) and is responsible for cellular transformation process that has been found in the case of vCrk and CRK-I (Takino et al., 2003). Thus, it is obvious that CRK is involved in the malignant process as an oncoprotein or through activation of downstream effectors (Table 1 ). 
Table 1. Genetic aberrations in NSCLC and SCLC

\begin{tabular}{|c|c|c|c|}
\hline \multirow[b]{2}{*}{ GENES } & \multirow[b]{2}{*}{ SCLC } & \multicolumn{2}{|c|}{ NSCLC } \\
\hline & & LADC & SQCLC \\
\hline \multicolumn{4}{|l|}{ ONCOGENIC ALTERATIONS } \\
\hline \multicolumn{4}{|l|}{ MUTATIONS } \\
\hline KRAS & $<1.0 \%$ & $15-35.0 \%$ & $<5.0 \%$ \\
\hline B-RAF & $<1.0 \%$ & $1-5.0 \%$ & $<1.0 \%$ \\
\hline EGFR & $<1.0 \%$ & $10-40.0 \%$ & $<1.0 \%$ \\
\hline ErbB2 (HER2) & $<1.0 \%$ & $4.0 \%$ & $<1.0 \%$ \\
\hline PIK3CA & $<1.0 \%$ & $<1.0 \%$ & $<5.0 \%$ \\
\hline MET & $13.0 \%$ & $14.0 \%$ & $12.0 \%$ \\
\hline \multicolumn{4}{|l|}{ GENE AMPLIFICATION } \\
\hline MYC & $18-30.0 \%$ & - & - \\
\hline EGFR & $<1.0 \%$ & $15.0 \%$ & $30.0 \%$ \\
\hline ErbB2 (HER2) & $5-30.0 \%$ & $6.0 \%$ & $2.0 \%$ \\
\hline MET & - & $20.0 \%$ & $21.0 \%$ \\
\hline PIK3CA & $5.0 \%$ & $6.0 \%$ & $33-36.0 \%$ \\
\hline MDM2 & - & $14.0 \%$ & $22.0 \%$ \\
\hline NKX2-1 (TITF1) & $<1.0 \%$ & $10-15.0 \%$ & $3-15.0 \%$ \\
\hline \multicolumn{4}{|l|}{$\begin{array}{l}\text { INCREASED PROTEIN } \\
\text { EXPRESSION }\end{array}$} \\
\hline MYC & $10-45.0 \%$ & - & - \\
\hline EGFR & $<1.0 \%$ & $40-65.0 \%$ & $60-85.0 \%$ \\
\hline ErbB2 (HER2) & $<10.0 \%$ & $16-38.0 \%$ & $6-16.0 \%$ \\
\hline BCL-2 & $75-95.0 \%$ & - & - \\
\hline c-KIT & $46-91.0 \%$ & - & - \\
\hline CCND1 (CYCLIN D1) & - & $35-55.0 \%$ & $30-35.0 \%$ \\
\hline CRK & - & $8-30.0 \%$ & - \\
\hline PDGFRA & $65.0 \%$ & $100.0 \%$ & $89.0 \%$ \\
\hline \multicolumn{4}{|l|}{ TELOMERES } \\
\hline TELOMERASE ACTIVITY & $75-100.0 \%$ & $65-85.0 \%$ & $80-90.0 \%$ \\
\hline \multicolumn{4}{|l|}{$\begin{array}{l}\text { CHROMOSOMAL } \\
\text { ABERRATIONS }\end{array}$} \\
\hline GAIN & $3 q, 5 p, 8 q, 18 q$ & $\begin{array}{c}5 p, 7 p, 7 q, 8 q \\
11 q, 19,20 q\end{array}$ & $\begin{array}{c}2 q, 3 q, 5 p, 8 q \\
7,8 q, 11 q, 13 q \\
19,20 q \\
\end{array}$ \\
\hline AMPLIFICATION & 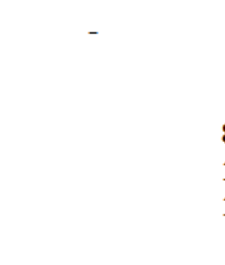 & $\begin{array}{r}1 \mathrm{p} 34.3,1 \mathrm{p} 36.3 \\
2 \mathrm{q} 31.1,2 q 11.2 \\
5 \mathrm{p} 15.33,5 q 31 \\
8 \mathrm{q} 21.13,8 \mathrm{q} 24.21 \\
12 \mathrm{p} 12.1,12 q 13.2 \\
14 q 13.3,16 \mathrm{q} 22.2 \\
19 q 13.33\end{array}$ & $\begin{array}{l}1 \mathrm{q} 32.2,2 \mathrm{p} 24.3, \\
5 \mathrm{p} 14.3,5 \mathrm{p} 15.31, \\
7 \mathrm{p} 11.2,8 \mathrm{p} 12, \\
10 \mathrm{q} 26.3,11 q 13.3, \\
12 q 15,14 q 32.13, \\
q 12.1,19 q 12, \\
22 q 11.21\end{array}$ \\
\hline
\end{tabular}




\section{References}

Anagnostou VK, Lowery FJ, Zolota V, Tzelepi V, Gopinath A, Liceaga C, Panagopoulos N, Frangia K, Tanoue L, Boffa D, Gettinger S, Detterbeck F, Homer RJ, Dougenis D, Rimm DL, Syrigos KN. High expression of BCL-2 predicts favorable outcome in non-small cell lung cancer patients with non squamous histology. BMC Cancer 2010; 10 : 186.

Anton RC, Brown RW, Younes M, Gondo MM, Stephenson MA, Cagle PT. Absence of prognostic significance of bcl-2 immunopositivity in non-small cell lung cancer: Analysis of 427cases. Hum Pathol 1997; 28: 1079-1082.

Ashman LK. The biology of stem cell factor and its receptor C-kit. Int J Biochem Cell Biol 1999; 31: 1037-1051.

Banerjee HN, Verma M. Epigenetic mechanisms in cancer. Biomark Med 2009; 3: 397-410.

Beau-Faller M, Ruppert AM, Voegeli AC, Neuville A, Meyer N, Guerin E, Legrain M, Mennecier B, Wihlm JM, Massard G, Quoix E, Oudet P, Gaub MP. MET gene copy number in non-small cell lung cancer: molecular analysis in a targeted tyrosine kinase inhibitor naive cohort. $J$ Thorac Oncol 20o8; 3: 331-339.

Bergethon K, Shaw AT, Ou SH, Katayama R, Lovly CM, McDonald NT, Massion PP, Siwak- Tapp C, Gonzalez A, Fang R, Mark EJ, Batten JM, Chen H, Wilner KD, Kwak EL, Clark JW, Carbone DP, Ji H, Engelman JA, MinoKenudson M, Pao W, Iafrate AJ. ROS1 rearrangements define a unique molecular class of lung cancers. $J$ Clin Oncol 2012; 30: 863-870.

Bingle CD. Thyroid transcription factor-1. Int J Biochem Cell Biol 1997; 29: 1471-1473.

Birge RB, Kalodimos C, Inagaki F, Tanaka S. Crk and CrkL adaptor proteins: networks for physiological and pathological signaling. Cell Commun Signal 2009; 7: 13.

Brambilla E, Moro D, Gazzeri S, Brambilla C. Alterations of the expression of Rb, p16(INK4A) and cyclin D1 in non-small cell lung carcinoma and their clinical significance. $J$ Pathol 1999; 188: 351-360.

Breuer RH, Postmus PE, Smit EF. Molecular pathology of non-small-cell lung cancer. Respiration 2005; 72: $313-330$

Broers JL, Viallet J, Jensen SM, Pass H, Travis WD, Minna JD, Linnoila RI.Expression of c-myc in progenitor cells of the Bronchopulmonary epithelium and in a large number of nonsmall cell lung cancers. Am J Respir Cell Mol Biol 1993; 9: 33-43.

Brose MS, Volpe P, Feldman M, Kumar M, Rishi I, Gerrero R, Einhorn E, Herlyn M, Minna J, Nicholson, Roth JA, Albelda SM, Davies H, Cox C, Brignell G, Stephens P, Futreal PA Wooster R, Stratton MR, Weber BL. BRAF and RAS mutations in human lung cancer and melanoma. Cancer Res 2002; 62: 6997-7000.

Cancer Genome Atlas Research Network. Comprehensive genomic characterization of squamous cell lung cancers. Nature 2012; 489: 519-525.

Cappuzzo F, Marchetti A, Skokan M, Rossi E, Gajapathy S, Felicioni L, Del Grammastro M, Sciarrotta MG, Buttitta F, Incarbone M, Toschi L, Finocchiaro G, Destro A, Terracciano L, Roncalli M, Alloisio M, Santoro A, VarellaGarcia M. MET increased gene copy number negatively affects survival of surgically resected non-small-cell lung cancer patients. J Clin Oncol 2009; 27: 1667-1674.

Chaft JE, Arcila ME, Paik PK, Lau C, Riely GJ, Pietanza MC, Zakowski MF, Rusch V, Sima CS, Ladanyi M, Kris MG. Coexistence of $\mathrm{PIK}_{3} \mathrm{CA}$ and other oncogene mutations in lung adenocarcinoma-rationale for comprehensive mutation profiling. Mol Cancer Ther 2012; 11: 485-491. 
Chen S, Xu Y, Chen Y, Li X, Mou W, Wang L, Liu Y, Reisfeld RA, Xiang R, Lv D, Li N. SOX2 gene regulates the transcriptional network of oncogenes and affects tumorigenesis of human lung cancer cells. PLoS One 2012; 7: e36326.

Chin LP, Soo RA, Soong R, Ou SH. Targeting ROS1 with anaplastic lymphoma kinase inhibitors: a promising therapeutic strategy for a newly defined molecular subset of nonsmall-cell lung cancer. J Thorac Oncol 2012; 7: 16251630 .

Cho YH, Yazici H, Wu HC, Terry MB, Gonzalez K, Qu M, Dalay N, Santella RM. Aberrant promoter hypermethylation and genomic hypomethylation in tumor, adjacent normal tissues and blood from breast cancer patients. Anticancer Res 2010; 30: 2489-2496.

Coltrera MD, Wang J, Porter PL, Gown AM. Expression of platelet-derived growth factor B- chain and the platelet-derived growth factor receptor beta subunit in human breast tissue and breast carcinoma. Cancer Res 1995; 55: $2703-2708$.

Cooper WA, Lam DCL, O’Toole SA, Minna JD. Molecular biology of lung cancer. J Thorac Dis 2013; 5: S479S490.

Courtney KD, Corcoran RB, Engelman JA. The PI3K pathway as drug target in human cancer. J Clin Oncol 2010; $28:$ 1075-1083.

Dahabreh IJ, Linardou H, Siannis F, Kosmidis P, Bafaloukos D, Murray S.Somatic EGFR mutation and and gene copy gain as predictive biomarkers for response to tyrosine kinase inhibitors in non-small cell lung cancer. Clin Cancer Res 2010; 16: 291-303.

Davies H, Bignell GR, Cox C, Stephens P, Edkins S, Clegg S, Teague J, Woffendin H, Garnett MJ, Bottomley W, Davis N, Dicks E, Ewing R, Floyd Y, Gray K, Hall S, Hawes R, Hughes J, Kosmidou V, Menzies A, Mould C, Parker A, Stevens C, Watt S, Hooper S, Wilson R, Jayatilake H, Gusterson BA, Cooper C, Shipley J, Hargrave D, PritchardsJones K, Maitland N, Chenevix-Trench G, Riggins GJ, Bigner DD, Palmieri G, Cossu A, Flanagan A, Nicholson A, Ho JW, Leung SY, Yuen ST, Weber BL, Seigler HF, Darrow TL, Paterson H, Marais R, Marshall CJ, Wooster R, Stratton MR, Futreal PA. Mutations of the BRAF gene in human cancer. Nature 2002; 417: 949-954.

Dearden S, Stevens J, Wu YL, Blowers D. Mutation incidence and coincidence in non small-cell lung cancer: meta-analyses by ethnicityand histology (mutMap). Ann Oncol/ESMO 2013; 24: 2371-2376.

Ding L, Getz G, Wheeler DA, Mardis ER, McLellan MD, Cibulskis K, Sougnez C, Greulich H, Muzny DM, Morgan MB, Fulton L, Fulton RS, Zhang Q, Wendl MC, Lawrence MS, Larson DE, Chen K, Dooling DJ, Sabo A, Hawes AC, Shen H, Jhangiani SN, Lewis LR, Hall O, Zhu Y, Mathew T, Ren Y, Yao J, Scherer SE, Clerc K, et al. Somatic mutations affect key pathways in lung adenocarcinoma. Nature 2008; 455: 1069-1075.

Downward J. Targeting RS signaling pathways in cancer therapy. Nat Rev Cancer 2003; 3: 11-22.

Dutt A, Ramos AH, Hammerman PS, Mermel C, Cho J, Sharifnia T, Chande A, Tanaka KE, Stransky N, Greulich H, Gray NS, Meyerson M. Inhibitor-sensitive FGFR1 amplification in human non-small cell lung cancer. PLoS One 2011; 6: e20351.

Engelman JA, Luo J, Cantley LC. The evolution of phosphatidylinositol 3-kinases as regulators of growth and metabolism. Nat Rev Genet 2006; 7: 606-619.

Engelman JA, Chen L, Tan X, Crosby K, Guimaraes AR, Upadhyay R, Maira M, McNamara K, Perera SA, Song Y, Chirieac LR, Kaur R, Lightbown A, Simendinger J, Li T, Padera RF, Garcia Echeverría C, Weissleder R, Mahmood U, 
Cantley LC, Wong KK. Effective use of PI3K and MEK inhibitors to treat mutant Kras G12D and PIK3CAH1047R murine lung cancers. Nat Med 2008; 14: 1351-1356.

Engelman JA, Zejnullahu K, Mitsudomi T, Song Y, Hyland C, Park JO, Lindeman N, Gale CM, Zhao X, Christensen J, Kosaka T, Holmes AJ, Rogers AM, Cappuzzo F, Mok T, Lee C, Johnson BE, Cantley LC, Jänne PA. MET amplification leads to gefitinib resistance in lung cancer by activating ERBB3 signaling. Science 2007; 316: 1039-1043.

Feller SM. Crk family adaptors-signaling complex formation and biological roles. Oncogene 2001; 20: 63486371.

Feng Q, Hawes SE, Stern JE, Wiens L, Lu H, Dong ZM, Jordan CD, Kiviat NB, Vesselle H. DNA methylation in tumor and matched normal tissues from non-small cell lung cancer patients. Cancer Epidemiol Biomarkers Prev 2008; 17: 645-654.

Fong KM, Kida Y, Zimmerman PV, Ikenaga M, Smith PJ. Loss of heterozygosity frequently affects chromosome17q in non-small cell lung cancer. Cancer Res 1995a; 55: 4268-4272

Fong KM, Sekido Y, Minna JD. Molecular pathogenesis of lung cancer. J Thorac Cardiovasc Surg 1999; 118: $1136-1152$.

Fong KM, Zimmerman PV, Smith PJ. Correlation of loss of heterozygosity at 11p with tumour progression and survival in non-small cell lung cancer. Genes Chromos Cancer 1994; 10: 183-189.

Fong KM, Zimmerman PV, Smith PJ. Microsatellite instability and other molecular abnormalities in nonsmall cell lung cancer. Cancer Res 1995b; 55: 28-30.

Fong KM, Zimmerman PV, Smith PJ. Tumor progression and loss of heterozygosity at 5q and 18q in non-small cell lung cancer. Cancer Res 1995c; 55: 220-223.

Fontanini G, Vignati S, Bigini D, Mussi A, Lucchi M, Angeletti CA, Basolo F, Bevilacqua G. Bcl-2 protein: a prognostic factor inversely correlated to p53 in non-small-cell lung cancer. Br J Cancer 1995; 71: 1003-1007.

Franklin WA, Veve R, Hirsch FR, Helfrich BA, Bunn PA Jr. Epidermal growth factor receptor family in lung cancer and premalignancy. Semin Oncol 2002; 29: 3-14.

Fujino S, Enokibori T, Tezuka N, Asada Y, Inoue S, Kato H, Mori A.A comparison of epidermal growth factor receptor levels and other prognostic parameters in non-small cell lung cancer. Eur J Cancer 1996; 32A: $2070-2074$.

Gaffney EF, O'Neil AJ, Staunton MJ. Bcl-2 and prognosis in non-small cell lung carcinoma. $N$ Engl J Med 1994; 330: 1757-1758.

Gao SP, Mark KG, Leslie K, Pao W, Motoi N, Gerald WL, Travis WD, Bornmann W, Veach D, Clarkson B, Bromberg JF. Mutations in the EGFR kinase domain mediate STAT3 activation via IL-6 production in human lung adenocarcinomas. J Clin Invest 2007; 117: 3846-3856.

Gao T, Wang S, He B, Yuqin Pan Y, Song G, Gu L, Chen L, Nie Z, Xu Y, Li R. The association of RAS association domain family Protein 1A (RASSF1A) methylation states and bladder cancer risk: a systematic review and metaanalysis. PLoS One 2012; 7: e48300.

Gautschi O, Ratschiller D, Gugger M, Betticher DC, Heighway J. Cyclin D1 in non- small cell lung cancer: a key driver of malignant transformation. Lung Cancer 2007 55: 1-14.

Gazdar AF. Should we continue to use the term non-small-cell lung cancer? Ann Oncol 2010; 21: 225-229. 
Gazdar AF. Activating and resistance mutations of EGFR in non-small-cell lung cancer: role in clinical response to EGFR tyrosine kinase inhibitors. Oncogene 2009; 28: S24-31.

Geutjes EJ, Bajpe PK, Bernards R.Targeting the epigenome for treatment of cancer. Oncogene 2012; 31: 38273844 .

Govindan R, Ding L, Grifth M, Subramanian J, Dees ND, Kanchi KL, Maher CA, Fulton R, Fulton L, Wallis J, Chen K, Walker J, McDonald S, Bose R, Ornitz D, Xiong D, You M, Dooling DJ, Watson M, Mardis ER, Wilson RK. Genomic landscape of non-small cell lung cancer in smokers and never-smokers. Cell 2012; 150: 1121-1134.

Graus-Porta D, Beerli RR, Daly JM, Hynes NE. ErbB-2, the preferred heterodimerization partner of all ErbB receptors, is a mediator of lateral signaling. EMBO $J$ 1997; 16: 1647-1655.

Sellers WR, Meyerson M. Oncogenic transformation by inhibitor-sensitive and- resistant EGFR mutants. PLoS Med 2005; 2: e313.

Hammerman PS, Sos ML, Ramos AH, Xu C, Dutt A, Zhou W, Brace LE, Woods BA, Lin W, Zhang J, Deng X, Lim SM, Heynck S, Peifer M, Simard JR, Lawrence MS, Onofrio RC, Salvesen HB, Seidel D, Zander T, Heuckmann JM, Soltermann A, Moch H, Koker M, Leenders F, Gabler F, Querings S, Ansén S, et al. Mutations in the DDR2 kinase gene identify a novel therapeutic target in squamous cell lung cancer. Cancer Discov 2011; 1: 78-89.

Heinmöller P, Gross C, Beyser K, Schmidtgen C, Maass G, Pedrocchi M, Rüschoff J. HER2 status in non-small cell lung cancer: results from patient screening for enrollment to a phase II study of herceptin. Clin Cancer Res 2003; 9: 5238-5243.

Heist RS, Sequist LV, Engelman JA. Genetic changes in squamous cell lung cancer: a review. $J$ Thorac Oncol 2012; 7: 924-933.

Herman JG, Baylin SB. Gene silencing in cancer in association with promoter hypermethylation. $N$ Engl $J$ Med 2003; 349: 2042-2054.

Hibi K, Takahashi T, Sekido Y, Ueda R, Hida T, Ariyoshi Y, Takagi H, Takahashi T. Coexpression of the stem cell factor and the c-kit genes in small-cell lung cancer. Oncogene 1991; 6: 2291-2296.

Higashiyama M, Doi O, Kodama K, Yokouchi H, Kasugai T, Ishiguro S, Takami K, Nakayama T, Nishisho I. MDM2 gene amplification and expression in non-small-cell lung cancer: immunohistochemical expression of its protein is a favourable prognostic marker in patients without p53 protein accumulation. Br J Cancer 1997; 75: 13021308.

Huang CH, Mandelker D, Schmidt-Kittler O, Samuels Y, Velculescu VE, Kinzler KW, Vogelstein B, Gabelli SB, Amzel LM. The structure of a human p110alpha/p85alpha complex elucidates the effects of oncogenic PI3K alpha mutations. Science 2007; 318: 1744-1748.

Hussenet T, Dali S, Exinger J, Monga B, Jost B, Dembelé D, Martinet N, Thibault C, Huelsken J, Brambilla E, du Manoir S. SOX2 is an oncogene activated by recurrent 3q26.3 amplifications in human lung squamous cell carcinomas. PLoS One 2010; 5: e8960

Ikeda K, Wang L, Torres R, Zhao H, Olaso E, Eng FJ, Labrador P, Klein R, Lovett D, Yancopoulos GD, Friedman SL, Lin HC. Discoidin domain receptor 2 interacts with Src and She following its activation by type I collagen. J Biol Chem 2002; 277: 19206-19212. 
Ikeda K, Clark JC, Shaw-White JR, Stahlman MT, Boutell CJ, Whitsett JA. Gene structure and expression of human thyroid transcription factor-1 in respiratory epithelial cells. $J$ Biol Chem 1995; 270: 8108-8114.

Ito M, Ito G, Kondo M, Uchiyama M, Fukui T, Mori S, Yoshioka H, Ueda Y, Shimokata K, Sekido Y. Frequent inactivation of RASSF1A, BLU, and SEMA3B on 3p21.3 by promoter hypermethylation and allele loss in non-small cell lung cancer. Cancer Lett 2005; 225: 131-139.

Jemal A, Siegel R, Xu J, Ward E.Cancer statistics, 2010. CA Cancer J Clin 2010; 60: 277-300.

Ju YS, Lee WC, Shin JY, Lee S, Bleazard T, Won JK, Kim YT, Kim JI, Kang JH, Seo JS. A transforming KIF5B and RET gene fusion in lung adenocarcinoma revealed from whole-genome and transcriptome sequencing. Genome Res 2012; 22 : 436-445.

Karachaliou N, Rosell R, Viteri S. The role of SOX2 in small cell lung cancer, lung adenocarcinoma and squamous cell carcinoma of the lung. Transl Lung Cancer Res 2013; 2: 172-179.

Kerr JF, Winterford CM, Harmon BV. Apoptosis. Its significance in cancer and cancer therapy. Cancer 1994; 73: 2013-2026.

Kohno T, Ichikawa H, Totoki Y, Yasuda K, Hiramoto M, Nammo T, Sakamoto H, Tsuta K, Furuta K, Shimada Y, Iwakawa R, Ogiwara H, Oike T, Enari M, et al. KIF5B-RET fusions in lung adenocarcinoma. Nat Med 2012; 18: 375377 .

Kosaka T, Yatabe Y, Endoh H, Kuwano H, Takahashi T, Mitsudomi T. Mutations of the epidermal growth factor receptor gene in lung cancer: biological and clinical implications. Cancer Res 2004; 64: 8919-8923.

Knudson AG. Antioncogenes and human cancer. Proc Natl Acad Sci USA 1993; 90: 10914-10921.

Knudson AG Jr. The ninth Gordon Hamilton-Fairley memorial lecture. Hereditary cancers: clues to mechanisms of carcinogenesis. Br J Cancer 1989; 59: 661-666.

Krystal GW, Hines SJ, Organ CP. Autocrine growth of small cell lung cancer mediated by coexpression pression of c-kit and stem cell factor. Cancer Res 1996; 56: 370-376.

Kurakawa E, Shimamoto T, Utsumi K, Hirano T, Kato H, Ohyashiki K. Hypermethylation of p16 (INK4a) and p15 (INK4b) genes in non-small cell lung cancer. Int J Oncol 2001; 19: 277-281.

Kwei KA, Kim YH, Girard L, Kao J, Pacyna-Gengelbach M, Salari K, Lee J, Choi YL, Sato M, Wang P, Hernandez-Boussard T, Gazdar AF, Petersen I, Minna JD, Pollack JR. Genomic profiling identifies TITF1 as a lineagespecific oncogene amplified in lung cancer. Oncogene 2008; 27: 3635-3640.

Larsen JE, Minna JD. Molecular Biology of Lung Cancer: Clinical Implications. Clin Chest Med 2011; 32: 703740.

Lawson MH, Cummings NM, Rassl DM, Vowler SL, Wickens M, Howat WJ, Brenton JD, Murphy G, Rintoul RC. Bcl-2 and beta1-integrin predict survival in a tissue microarray of small cell lung cancer. Br J Cancer 2010; 103: $1710-1715$.

Lipson D, Capelleti M, Yelensky R, Otto G, Parker A, Jarosz M, Curran JA, Balasubramanian S, Bloom T, Brennan KW, Donahue A, Downing SR, Frampton GM, Garcia L, Juhn F, Mitchell KC, White E, White J, Zwirko Z, Peretz T, Nechushtan $\mathrm{H}$ et al. Identification of new ALK and RET gene fusions from colorectal and lung cancer biopsies. Nat Med 2012; 18: 382-384. 
Maier S, Wilbertz T, Braun M, Scheble V, Reischl M, Mikut R, Menon R, Nikolov P, Petersen K. Beschorner C, Moch H, Kakies C, Protzel C, Bauer J, Soltermann A, Fend F, Staebler A, Lengerke C, Perner S. SOX2 amplification is a common event in squamous cell carcinomas of different organ sites. Hum Pathol 2011; 42: 1078-1088.

Marcheti A, Felicioni L, Malatesta S, Grazia Sciarrotta M, Guetti L, Chella A, Viola P, Pullara C, Mucilli F, Buttitta F. Clinical features and outcome of patients with non-small cell lung cancer harboring BRAF mutations. J Clin Oncol 2011; 29: 3574-3579.

Marks JL, Gong Y, Chitale D, Golas B, McLellan MD, Kasai Y, Ding L, Mardis ER, Wilson RK, Solit D, Levine R, Michel K, Thomas RK, Rusch VW, Ladanyi M, Pao W. Novel MEK1 mutation identified by mutational analysis of epidermal growth factor receptor signaling pathway genes in lung adenocarcinoma. Cancer Res 2008; 68: 5524-5528.

Mayer BJ, Hamaguchi M, Hanafusa H. Characterization of p47 gag-crk, a novel oncogene product with sequence similarity to a putative modulatory domain of protein-tyrosine kinases and phospholipase C. Cold Spring Harb Symp Quant Biol 1988; 53: 907-914.

McDonnell TJ, Marin MC, Hsu B, Brisbay SM, McConnell K, Tu SM, Campbell ML, Rodriguez- Villanueva J. The bcl-2 oncogene: apoptosis and neoplasia. Radiat Res 1993; 136: 307-312.

Miller CT, Chen G, Gharib TG, Wang H, Thomas DG, Misek DE, Giordano TJ, Yee J, Orringer MB, Hanash SM, Beer DG. Increased C-CRK proto-oncogene expression is associated with an aggressive phenotype in lung adenocarcinomas. Oncogene 2003; 22: 7950-7957.

Montmayeur JP, Valius M, Vandenheede J, Kazlauskas A. The platelet-derived growth factor beta receptor triggers multiple cytoplasmic signaling cascades that arrive at the nucleus as distinguishable inputs. J Biol Chem 1997; 272: $32670-32678$.

Nau MM, Brooks BJ Jr, Carney DN Gazdar AF, Battey JF, Sausville EA, Minna JD. Human small-cell lung cancers show amplification and expression of the N-myc gene. Proc Natl Acad Sci USA 1986; 83: $1092-1096$.

Normanno N, Bianco C, Strizzi L, Mancino M, Maiello MR, De Luca A, Caponigro F, Salomon DS. The ErbB receptors and their ligands in cancer: an overview. Curr Drug Targets 2005; 6: 243-257.

Nowell PC. The clonal evolution of tumor cell populations. Science 1976; 194: 23-28.

Ohtsuka K, Ohnishi H, Fujiwara M, Kishino T, Matsushima S, Furuyashiki G, Takei H, Koshiishi Y, Goya T, Watanabe T. Abnormalities of epidermal growth factor receptor in lung squamous-cell carcinomas, adenosquamous carcinomas, and large cell carcinomas: tyrosine kinase domain mutations are not rare in tumors with an adenocarcinoma component. Cancer 2007; 109: 741-750.

Okabe T, Okamoto I, Tamura K, Terashima M, Yoshida T, Satoh T, Takada M, Fukuoka M, Nakagawa K. Differential constitutive activation of the epidermal growth factor receptor in non-small cell lung cancer cells bearing EGFR gene mutation and amplification. Cancer Res 2007; 67: 2046-2053.

O'Neill AJ, Staunton MJ, Gaffney EF. Apoptosis occurs independently of bcl-2 and p53 overexpression in nonsmall cell lung carcinoma. Histopathology 1996; 29: 45-50.

Onozato R, Kosaka T, Kuwano H, Sekido Y, Yatabe Y, Mitsudomi T. Activtion of MET by gene amplification or by splice mutations deleting the juxtamembrane domain in primary resected lung cancers. J Thorac Oncol 2009; 4: 511. 
Paik PK, Arcila ME, Fara M, Sima CS, Miller VA, Kris MG, Ladanyi M, Riely GJ. Clinical characteristics of patients with lung adenocarcinomas harboring BRAF mutations. J Clin Oncol 2011; 29: 2046-2051.

Pao W, Wang TY, Riely GJ, Miller VA, Pan Q, Ladanyi M, Zakowski MF, Heelan RT, Kris MG, Varmus HE. KRAS mutations and primary resistance of lung adenocarcinomas to gefitinib or erlotinib. PLoS Med 2005 ; 2 : e17.

Pao W, Miller VA, Politi KA, Riely GJ, Somwar R, Zakowski MF, Kris MG, Varmus H. Acquired resistance of lung adenocarcinomas to gefitinib or erlotinib is associated with a second mutation in the EGFR kinase domain. PLoS Med 2005; 2: e73.

Pezzella F, Turley H, Kuzu I, Tungekar MF, Dunnill MS, Pierce CB, Harris A, Gatter KC, Mason DY. Bcl-2 protein in non-small-cell lung carcinoma. N Engl J Med 1993; 2: 690-694.

Rekhtman N, Paik PK, Arcila ME, Tafe LJ, Oxnard GR, Moreira AL, Travis WD, Zakowski MF, Kris MG, Ladanyi M. Clarifying the spectrum of driver oncogene mutations in biomarker-verified squamous carcinoma of lung: lack of EGFR/KRAS and presence of PIK3CA/AKT1 mutations. Clin Cancer Res 2012; 18:

Riely GJ, Kris MG, Rosenbaum D, Marks J, Li A, Chitale DA, Nafa K, Riedel ER, Hsu M, Pao W, Miller, VA, Ladanyi M. Frequency and distinctive spectrum of KRAS mutations in never smokers with lung adenocarcinoma. Clin Cancer Res 2008; 14: 5731-5734.

Richardson GE, Johnson BE. The biology of lung cancer. Semin Oncol 1993; 20(2): 105-127.

Rikova K, Guo A, Zeng Q. Global survey of phosphotyrosine signaling identifies oncogenic kinases in lung cancer. Cell 2007; 131: 1190-1203.

Rudin CM, Durinck S, Stawiski EW, Poirier JT, Modrusan Z, Shames DS, Bergbower EA, Guan Y, Shin J, Rivers CS, Foo CK, Bhatt D, Stinson J, Gnad F, Haverty PM, Gentleman R, Chaudhuri S, Janakiraman V, Jaiswal BS, Parikh C, Yuan W, Zhang Z. Comprehensive genomic analysis identifies SOX2 as a frequently amplified gene in smallcell lung cancer. Nat Genet 2012; 44: 1111-1116.

Sadiq AA, Salgia R. MET as a possible target for non-small-cell lung cancer. J Clin Oncol 2013; 31: 1089-1096. Samuels Y, Velculescu VE. Oncogenic mutations of PIK3CA in human cancers. Cell Cycle 2004; 3: 1221-1224. Sanchez-Cespedes M, Ahrendt SA, Piantadosi S, Rosell R, Monzo M, Wu L, Westra WH, Yang SC, Jen J, Sidransky D. Chromosomal alterations in lung adenocarcinoma from smokers and nonsmokers. Cancer Res 2001; 61: 1309-1313.

Scaglioti GV, Selvaggi G, Novello S, Hirsch FR. The Biology of epidermal growth factor receptor in lung cancer. Clin Cancer Res 2004; 10: 4227s-4232s.

Schmid K, Oehl N, Wirba F, Pirker R, Pirker C, Filipits M. EGFR/KRAS/BRAF mutations in primary lung ADC and corresponding locoregional lymph node metastases. Clin Cancer Res 2009; 15: 4554-4560.

Sekido Y, Fong KM, Minna JD. Progress in understanding the molecular pathogenesis of human lung cancer. Biochim Biophys Acta 1998; 1378: F21-59.

Sekido Y, Fong KM, Minna JD. Molecular genetics of lung cancer. Annu Rev Med 2003; 54: 73-87.

Sharma S, Kelly TK, Jones PA. Epigenetics in cancer. Carcinogenesis 2010; 31: 27-36.

Shaw AT, Yeap BY, Mino-Kenudson M, Digumarthy SR, Costa DB, Heist RS, Solomon B, Stubbs H, Admane S, McDermott U, Settleman J, Kobayashi S, Mark EJ, Rodig SJ, Chirieac LR, Kwak EL, Lynch TJ, Iafrate AJ. Clinical 
features and outcome of patients with non-small-cell lung cancer who harbor EML4ALK. J Clin Oncol 2009; 27: 42474253.

Shigematsu H, Takahashi T, Nomura M, Majmudar K, Suzuki M, Lee H, Wistuba II, Fong KM, Toyooka S, Shimizu N, Fujisawa T, Minna JD, Gazdar AF. Somatic mutations of the HER2 kinase domain in lung adenocarcinomas. Cancer Res 2005; 65: 1642-1646.

Shigematsu H, Lin L, Takahashi T, Nomura M, Suzuki M, Wistuba II, Fong KM, Lee H, Toyooka S, Shimizu N, Fujisawa T, Feng Z, Roth JA, Herz J, Minna JD, Gazdar AF. Clinical and biological features associated with epidermal growth factor receptor gene mutations in lung cancers. J Natl Cancer Inst 2005; 97: 339-346.

Shim AH, Liu H, Focia PJ, Chen X, Lin PC, He X. Structures of a platelet-derived growth factor/propeptide complex and a platelet-derived growth factor/receptor complex. Proc Natl Acad Sci USA 2010; 107: 11307-11312.

Siprashvili Z, Sozzi G, Barnes LD, McCue P, Robinson AK, Eryomin V, Sard L, Tagliabue E, Greco A, Fusetti L, Schwartz G, Pierotti MA, Croce CM, Huebner K.Replacement of Fhit in cancer cells suppresses tumorigenicity. Proc Natl Acad Sci USA 1997; 94: 13771-13776.

Sholl LM, Barletta JA, Yeap BY, Chirieac LR, Hornick JL. Sox2 protein expression is an independent poor prognostic indicator in stage I lung adenocarcinoma. Am J Surg Pathol 2010; 34: 1193-1198.

Sholl LM, Long KB, Hornick JL. Sox2 expression in pulmonary non-small cell and neuroendocrine carcinomas. Appl Immunohistochem Mol Morphol 2010; 18: 55-61.

Sordella R, Bell DW, Haber DA, Settleman J. Gefitinib-sensitizing EGFR mutations in lung cancer activate anti-apoptotic pathways. Science 2004; 305: 1163-1167.

Sulewska A, Niklinska W, Kozlowski M, Minarowski L, Naumnik W, Niklinski J, Dabrowska K, Chyczewski L. DNA methylation in states of cell physiology and pathology. Folia Histochem Cytobiol 2007; 45: 149-158.

Takeuchi K, Soda M, Togashi Y, Suzuki R, Sakata S, Hatano S, Asaka R, Hamanaka W, Ninomiya H, Uehara H, Lim Choi Y, Satoh Y, Okumura S, Nakagawa K, Mano H, Ishikawa Y. RET, ROS1 and ALK fusions in lung cancer. Nature Med 2012; 18: 378-381.

Takino T, Nakada M, Miyamori H, Yamashita J, Yamada KM, Sato H. CrkI adapter protein modulates cell migration and invasion in glioblastoma. Cancer Res 2003; 63: 2335-2337.

Tam IY, Chung LP, Suen WS, Wang E, Wong MC, Ho KK, Lam WK, Chiu SW, Girard L, Minna JD, Gazdar AF, Wong MP. Distinct epidermal growth factor receptor and KRAS mutation patterns in non-small cell lung cancer patients with different tobacco exposure and clinicopathologic features. Clin Cancer Res 2006; 12: $1647-1653$.

Tanaka H, Yanagisawa K, Shinjo K, Taguchi A, Maeno K, Tomida S, Shimada Y, Osada H, Kosaka T, Matsubara H, Mitsudomi T, Sekido Y, Tanimoto M, Yatabe Y, Takaha Shi T. Line age specific dependency of lung adenocarcinomas on the lung development regulator TTF-1. Cancer Res 2007; 67: 6007-6011.

Tang X, Khuri FR, Lee JJ, Kemp BL, Liu D, Hong WK, Mao L. Hypermethylation of the death-associated protein (DAP) kinase promoter and aggressiveness in stage I non small-cell lung cancer. J Natl Cancer Inst 2000; 92: 1460-1461.

Tejada ML, Yu L, Dong J, Jung K, Meng G, Peale FV, Frantz GD, Hall L, Liang X, Gerber HP, Ferrara N. Tumor-driven paracrine platelet-derived growth factor receptor alpha signaling is a key determinant of stromal cell recruitment in a model of human lung carcinoma. Clin Cancer Res 2006; 12: 2676-2688. 
Tian Y, Chu Q, Chen Y. Progress of platelet derived grow factor family in non-small cell lung cancer. Chin $J$ Lung Cancer 2014; 17: 42-48.

Tomizawa K, Suda K, Onozato R, Kosaka T, Endoh H, Sekido Y, Shigematsu H, Kuwano H, Yatabe Y, Mitsudomi T. Prognostic and predictive implications of HER2/ERBB2/neu gene mutations in lung cancers. Lung Cancer 2011; 74: 139-144.

Tran TN, Selinger CI, Kohonen-Corish MR, McCaughan BC, Kennedy CW, O'Toole SA, Cooper WA. Fibroblast Growth Factor Receptor 1 (FGFR1) copy number is an independent prognostic factor in non-small cell lung cancer. Lung Cancer 2013; 81: 462-467.

Turner N, Grose R. Fibroblast growth factor signaling: from development to cancer. Nat Rev Cancer 2010; 10: 116-129.

Valiathan RR, Marco M, Leitinger B, Kleer CG, Fridman R. Discoidin domain receptor tyrosine kinases: new players in cancer progression. Cancer Metastasis Rev 2012; 31: 295-321.

World Cancer Report 2014. World Health Organization. 2014. pp. Chapter 5.1

World Cancer Report 2014. World Health Organization. 2014. pp. Chapter 1.1.

Wells SA Jr, Santoro M. Targeting the RET pathway in thyroid cancer. Clin Cancer Res 2009; 15: 7119-7123.

Weir BA, Woo MS, Getz G, Perner S, Ding L, Beroukhim R, Lin WM, Province MA, Kraja A, Johnson LA, Shah K, Sato M, Thomas RK, Barletta JA, Borecki IB, Broderick S, Chang AC, Chiang DY, Chirieac LR, Cho J, Fujii Y, Gazdar AF, Giordano T, Greulich H, Hanna M, Johnson BE, Kris MG et al. Characterizing the cancer genome in lung adenocarcinoma. Nature 2007; 450: 893-898.

Winslow MM, Dayton TL, Verhaak RG, Kim-Kiselak C, Snyder EL, Feldser DM, Hubbard DD, DuPage MJ, Whittaker CA, Hoersch S, Yoon S, Crowley D, Bronson RT, Chiang DY, Meyerson M, Jacks T. Suppression of lung adenocarcinoma progression by Nkx2-1. Nature 2011; 473: 101-104.

Wistuba II, Behrens C, Virmani AK, Mele G, Milchgrub S, Girard L, Fondon JW 3rd, Garner HR, McKay B, Latif F, Lerman MI, Lam S, Gazdar AF, Minna JD. High resolution chromosome 3p allelotyping of human lung cancer and preneoplastic / preinvasive bronchial epithelium reveals multiple, discontinuous sites of $3 p$ allele loss and three regions of frequent breakpoints. Cancer Res 2000; 60: 1949-1960. cancer. Lung cancer 2009; 63: 315-321.

Yamamoto H, Shigematsu H, Nomura M, Lockwood WW, Sato M, Okumura N, Soh J, Suzuki M, Wistuba II, Fong KM, Lee H, Toyooka S, Date H, Lam WL, Minna JD, Gazdar AF. PIK3CA mutations and copy number gains in human lung cancers. Cancer Res 2008; 68: 6913-6921.

Yang L, Lin M, Ruan WJ, Dong LL, Chen EG, Wu XH, Ying KJ.Nkx2-1: a novel tumor biomarker of lung cancer. J Zhejiang Univ Sci B 2012; 13: 855-866.

Yarden Y, Kuang WJ, Yang-Feng T, Coussens L, Munemitsu S, Dull TJ, Chen E, Schlessinger J, Francke U, Ullrich A. Human proto-oncogene c-kit: a new cell surface receptor tyrosine kinase for an unidentified ligand. EMBO $J$ 1987; 6: 3341-3351.

Yip PY, Yu B, Cooper WA, Selinger CI, Ng CC, Kennedy CW, Kohonen-Corish MR, McCaughan BC, Trent RJ, Boyer MJ, Kench JG, Horvath LG, O'Toole SA. Patterns of DNA mutations and ALK rearrangement in resected node negative lung adenocarcinoma. J Thorac Oncol 2013; 8: 408-414. 
Global Journal of Cancer Case Reports | April 2020 | Volume 01 | Issue 02 | PAGE 1-22

Chrysanthakopoulos NA., Molecular and Biological Basis of Lung Cancer-Part I

Yuan TL, Cantley LC. PI3K pathway alterations in cancer: variations on a theme. Oncogene 2008; 27: 54975510.

Zochbauer-Muller S, Minna JD, Gazdar AF. Aberrant DNA methylation in lung cancer: biological and clinical implications. Oncologist 2002; 7: 451-457. 